\title{
Potensi dan Karakteristik Bakteri Simbion Karang Lunak Sinularia sp. sebagai Anti Bakteri Escherichia coli dari Perairan Pulau Gili Labak Madura Indonesia
}

\author{
Eka Nurrahema Ning Asih*, Ary Giri Dwi Kartika \\ Program Studi Ilmu Kelautan, Fakultas Pertanian, Universitas Trunojoyo Madura \\ Jl. Raya Telang, Telang-Kamal, Bangkalan, Jawa Timur 69162 Indonesia \\ ${ }^{*}$ Corresponding author, e-mail: eka.asih@trunojoyo.ac.id
}

\begin{abstract}
ABSTRAK: Gili Labak merupakan pulau kecil di Kabupaten Sumenep-Madura yang memiliki keanekaragaman karang lunak melimpah salah satunya Sinularia sp.. Beberapa studi literatur menyatakan bahwa Sinularia sp. memiliki berbagai jenis bakteri simbion yang berperan penting dalam siklus hidup karang lunak ini. Bakteri yang bersimbiosis dengan Sinularia sp. memiliki potensi besar sebagai agen anti bakteri khususnya bakteri gram negatif Escherichia coli. Identifikasi isolat bakteri yang bersimbiosis dengan Sinularia sp. ini merupakan alternatif upaya pemanfaatan sumberdaya karang lunak secara konservatif dan keberlanjutan. Penelitian ini bertujuan untuk mengetahui potensi anti bakteri dan mengidentifikasi jenis bakteri simbion dari ekstrak karang lunak Sinularia Sp. yang berasal dari perairan Gili Labak Madura. Metode yang digunakan dalam penelitian ini adalah uji zona hambat bakteri menggunakan overlay dan metode difusi dengan media ZoBell 2216E. Karakteristik molekuler sampel diamati menggunakan metode PCR 16s rDNA dengan ekstraksi DNA menggunakan Chelex 100 dan Primer amplifikasi PCR 27F dan 1492R. Pohon filogenetik dibangun dengan menggunakan aplikasi MEGA 6. Hasil penelitian diketahui dari 4 isolat bakteri (L2.2, L2.3, L2.4, dan L2.5), terdapat 1 isolat yang yang memiliki aktivitas antibakteri Escherichia coli kuat yaitu Isolat L2.5. Isolat L2.5 memiliki diameter zona hambat terbesar yaitu $2.207 \pm 0.401 \mathrm{~cm}$. Strain bakteri aktif di Isolat L2.5 adalah Virgibacillus marismortui dengan kemiripan urutan $100 \%$. Hasil penelitian ini menjadi informasi awal yang dapat digunakan sebagai referensi untuk mengoptimalkan potensi pemanfaatan bakteri Virgibacillus marismortui di bidang bioteknologi laut khususnya industri farmasi di masa yang akan datang.
\end{abstract}

Kata kunci: Escherichia coli; Sinularia sp.; Virgibacillus marismortui; Zona hambat bakteri

\section{Potential and Characteristics of Bacteria Associated with Sinularia sp. as Escherichia coli Antibacterial from Gili Labak Madura Waters}

\begin{abstract}
Gili Labak is a small island in Madura district which has a diversity of soft coral Sinularia sp. Several literature studies state that Sinularia sp. has various types of symbiotic bacteria that play an important role in the life cycle of this soft coral. This symbiotic bacterium with Sinularia sp. has great potential as an antibacterial agent especially inhibiting of gram-negative bacteria Escherichia coli. Identification of bacterial isolates that are in symbiosis with Sinularia $s p$. is an alternative to conservative and sustainable use of soft coral resources. This study aims to determine the anti-bacterial potential and identify the type of bacteria from the soft coral extract of Sinularia sp. from the waters of Gili Labak-Madura. The method used in this research is bacterial inhibition zone test using overlay and diffusion methods with ZoBell $2216 E$ media. Molecular characteristics of samples were observed using PCR 16s rDNA method with DNA extraction using Chelex 100 and PCR amplification primers 27F and 1492R. Phylogenetic trees were constructed using MEGA 6 application. The results showed that there were 4 isolates (L2.2, L2.3, L2.4, and L2.5), there was 1 isolate that had strong Escherichia coli antibacterial activity, namely Isolate L2.5. L2.5 isolate has the largest inhibitory zone diameter of $2.207 \pm 0.401 \mathrm{~cm}$. The active bacterial strain in the L2.5 isolate was Virgibacillus marismortui with $100 \%$ sequence similarity. The results of this study serve as initial information that can be used as a reference to optimize the potential utilization of Virgibacillus marismortui bacteria in marine biotechnology, especially the pharmaceutical industry in the future.
\end{abstract}

Keywords: Escherichia coli; Sinularia sp.; Virgibacillus marismortui; Bacterial inhibition zone. 


\section{PENDAHULUAN}

Ekosistem terumbu karang merupakan ekosistem hayati laut kompleks yang bersifat multi peran diantaranya berperan penting bagi ekologis, ekonomi, wisata, kimia dan biologis (Salanggon dan Finarti, 2016). Salah satu peran penting terumbu karang khususnya karang lunak pada sektor ekonomi yaitu sebagai marine natural product, karena biota ini memiliki suatu subtansi yang berperan sebagai bahan aktif yang disebut kandungan senyawa bioaktif (Rozirwan et al., 2014). Kandungan senyawa bioaktif pada karang lunak terbentuk dari hasil metabolit sekunder. Senyawa bioaktif yang diproduksi oleh karang lunak ini digunakan sebagai alat mempertahankan diri dari acaman yang ada di sekitar ekosistem terumbu karang (Tanod et al., 2019). Karang lunak juga memiliki sifat allelopatik yaitu kemampuan tubuh biota ini untuk mengeluarkan zat tertentu yang biasanya digunakan sebagai alat perlindungan diri dari predator (Chen et al., 2012).

Salah satu genus karang lunak yang mendominasi dan banyak di temukan di perairan laut Indonesia adalah Sinularia (Dewanto et al., 2019). Karang lunak Sinularia sp. tumbuh dan berkembang biak secara optimal pada rata-rata suhu perairan berkisar $23-25^{\circ} \mathrm{C}$ dan salinitas sebesar 32-35\%. Sinularia sp. memiliki potensi besar sebagai bahan baku farmasi karena biota ini menghasilkan beberapa senyawa bioaktif diantaranya terpen (Kamel dan Slattery, 2005), diterpenes flexibilide dan sinulariolide (Aceret et al., 1998), senyawa sinugran-disterols A-D dan trihydroxysteroids (Ahmed et al., 2007), cembrane diterpenoids (Lin et al., 2009), steroid hurgadacin (Shaaban et al., 2013) dan sesquiterpenoids capillosananes S-Z (Chen et al., 2014). Senyawa-senyawa bioaktif pada Sinularia sp. ini berfungsi sebagai senyawa bioaktif yang berperan menghabat aktivitas bakteri atau dikenal sebagai anti bakteri (Rozirwan et al., 2014), antivirus dan anti inflamasi (Cheng et al., 2010), penghambat aktivitas NFkB dan iNOS (Riyadi et al., 2019) dan penghambat aktivitas NO (Fattorusso et al., 2011 dan Putra et al., 2012).

Gili Labak adalah salah satu pulau kecil di Kabupaten Sumenep-Madura yang berdasarkan hasil foto citra LDCM (Landsat Data Continuity Mission) memiliki luas terumbu karang sebesar 66 ha dengan rincian luas terumbu karang hidup yaitu 49.089,6 $\mathrm{cm}^{2}$ dan luas terumbu karang mati yaitu 51.654,6 $\mathrm{cm}^{2}$ (Muhsoni, 2017). Pulau ini yang memiliki keanekaragaman karang lunak melimpah salah satunya Sinularia sp. Beberapa literatur menyatakan bahwa ekstrak Sinularia sp. memiliki aneka ragam senyawa bioaktif misalnya steroid. Steroid yang terkandung dalam Sinularia sp. tergolong senyawa bioaktif yang berfungsi sebagai anti bakteri (Rajaram et al., 2014) dan berpotensi menghambat pertumbuhan Escherichia coli sebesar 80-90\% (Salanggon et al., 2020). Pemanfaatan Sinularia sp. sebagai sumber anti bakteri Escherichia coli membutuhkan kajian yang cermat karena kegiatan ini secara tidak langsung dapat mengancam populasi karang lunak Sinularia sp. di perairan khususnya perairan Gili Labak. Salah satu upaya konservatif dalam pemanfaatan Sinularia sp. sebagai anti bakteri Escherichia coli adalah dengan memanfaatkan mikroorganisme berupa bakteri yang bersimbiosis dengan karang lunak tersebut. Identifikasi potensi dan karakteristik bakteri simbion karang lunak Sinularia sp. sebagai anti bakteri Escherichia coli dari perairan pulau Gili Labak Madura perlu dilakukan sebagai upaya menemukan informasi tentang pemanfaatan bakteri simbion Sinularia sp. sebagai anti bakteri dengan tidak mengganggu populasi karang ini di alam. Hal inilah yang melatarbelakangi penelitian ini dilaksanakan. Tujuan dari penelitian ini untuk mengetahui potensi anti bakteri dan mengidentifikasi jenis bakteri simbion dari ekstrak karang lunak Sinularia sp. yang berasal dari perairan Gili Labak Madura.

\section{MATERI DAN METODE}

Sampel Sinularia sp. dikumpulkan dari perairan Gili Labak Kabupaten Sumenep-Madura menggunakan Scuba diving dengan kedalaman 7-11 meter pada titik koordinat 07012'17.2" LS dan $114^{\circ} 02^{\prime} 59.9^{\prime \prime}$ BT (Gambar 1). Sampel yang telah dikolektif kemudian disimpan dengan cara dimasukkan kedalam plastik zip lock dan dimasukkan ke dalam cool box. Sampel selanjutnya dibawa ke Laboratorium Bioteknologi Prodi IImu Kelautan Universitas Trunojoyo Madura untuk dilakukan isolasi bakteri. Isolasi bakteri dilakukan dengan menghancurkan sampel Sinularia sp. menggunakan mortar dan alu steril. Sampel halus dihomogenkan dengan $9 \mathrm{~mL}$ air laut sebagai pengenceran $10^{-0}$, kemudian dilakukan pengenceran berkala yaitu dari pengenceran $10^{-1}$ sampai 
$10^{-5}$. Setiap pengenceran $10^{-3}, 10^{-4}$ dan $10^{-5}$ dicuplik sebanyak $100 \mu \mathrm{L}$ lalu disebar di atas media agar half strength zobell 2216E dan diinkubasi selama 48 jam pada suhu kamar (Benson, 2002).

\section{Uji Zona Hambat Bakteri (Sabdono dan Radjasa, 2006)}

Uji zona hambat bakteri simbion karang lunak Sinularia sp. terhadap bakteri Escherichia coli dilakukan dengan metode overlay (Sabdono dan Radjasa, 2006) dan metode difusi agar (Radjasa et al, 2007). Metode overlay dimulai dengan cara mengambil satu ose bakteri simbion Sinularia sp. ditanam pada media ZoBell 2216E laut dengan bentuk bulatan kecil sebanyak 5 - 12 titik bakteri dalam 1 cawan petri. Sampel biakan tersebut diinkubasi pada suhu kamar selama 2 hari. Isolat bakteri Escherichia coli ditanam pada media cair Zobell 2216E kemudian homogenkan dengan rotary shaker selama $2 \times 24$ jam. Suspensi bakteri Escherichia coli tersebut kemudian diambil $1 \mathrm{~mL}$ ( $1 \%$ dari total volume soft agar) dan dimasukkan ke dalam $100 \mathrm{~mL}$ media Zobell 2216E soft agar. Aktivitas zona hambat bakteri diamati dengan indikator terbentuknya zona bening pada biakan bakteri Escherichia coli pada media Zobell 2216E soft agar yang telah dituangkan kedalam cawan petri yang berisi biakan bakteri simbion Sinularia sp.

Metode difusi agar dimulai dari membuat biakan bakteri Escherichia coli dengan cara mengambil $100 \mu \mathrm{L}$ bakteri Escherichia coli pada fase log $\left(10^{9} \mathrm{sel} / \mathrm{mL}\right)$ disebar diatas media agar zobell 2216E. Biakan bakteri Escherichia coli tersebut kemudiaspn diberi sepuluh kertas cakram yang telah berisi bakteri Sinularia sp. di atas permukaannya dan diinkubasi pada suhu kamar selama 48 jam. Aktivitas antibakteri ditunjukkan dengan terbentuknya clear zone disekitar kertas cakram.

\section{Ekstraksi DNA (Walsh et al., 1991)}

Ekstraksi DNA dilakukan dengan menggunakan Chelex 100 menurut Walsh et al., (1991). Sel bakteri simbion Sinularia sp. diambil dan dimasukkan ke dalam mikrotube steril berisi $100 \mu \mathrm{L}$ Aquabides $\left(\mathrm{ddH}_{2} \mathrm{O}\right)$ dan $1 \mathrm{~mL}$ Saponin 0,5\% dalam PBS. Simpan sampel tersebut selama 24 jam pada suhu $40^{\circ} \mathrm{C}$. Sampel bakteri dalam mikrotube yang telah disimpan 24 jam tersebut disentrifuge dengan kecepatan $12.000 \mathrm{rpm}$ selama 10 menit dan pisahkan supernatannya. Sampel ditambahkan $1 \mathrm{~mL}$ dd $\mathrm{H}_{2} \mathrm{O}$ steril dalam PBS kemudian dicentrifuge kembali dan pisahkan supernatannya untuk mencuci atau menghilangkan residu saponin. Pelet yang telah bebas dari residu saponin tersebut ditambahkan $100 \mu \mathrm{L}$ Aquabides $\left(\mathrm{ddH}_{2} \mathrm{O}\right)$ dan $50 \mu \mathrm{L}$ Chelex $10020 \%$,

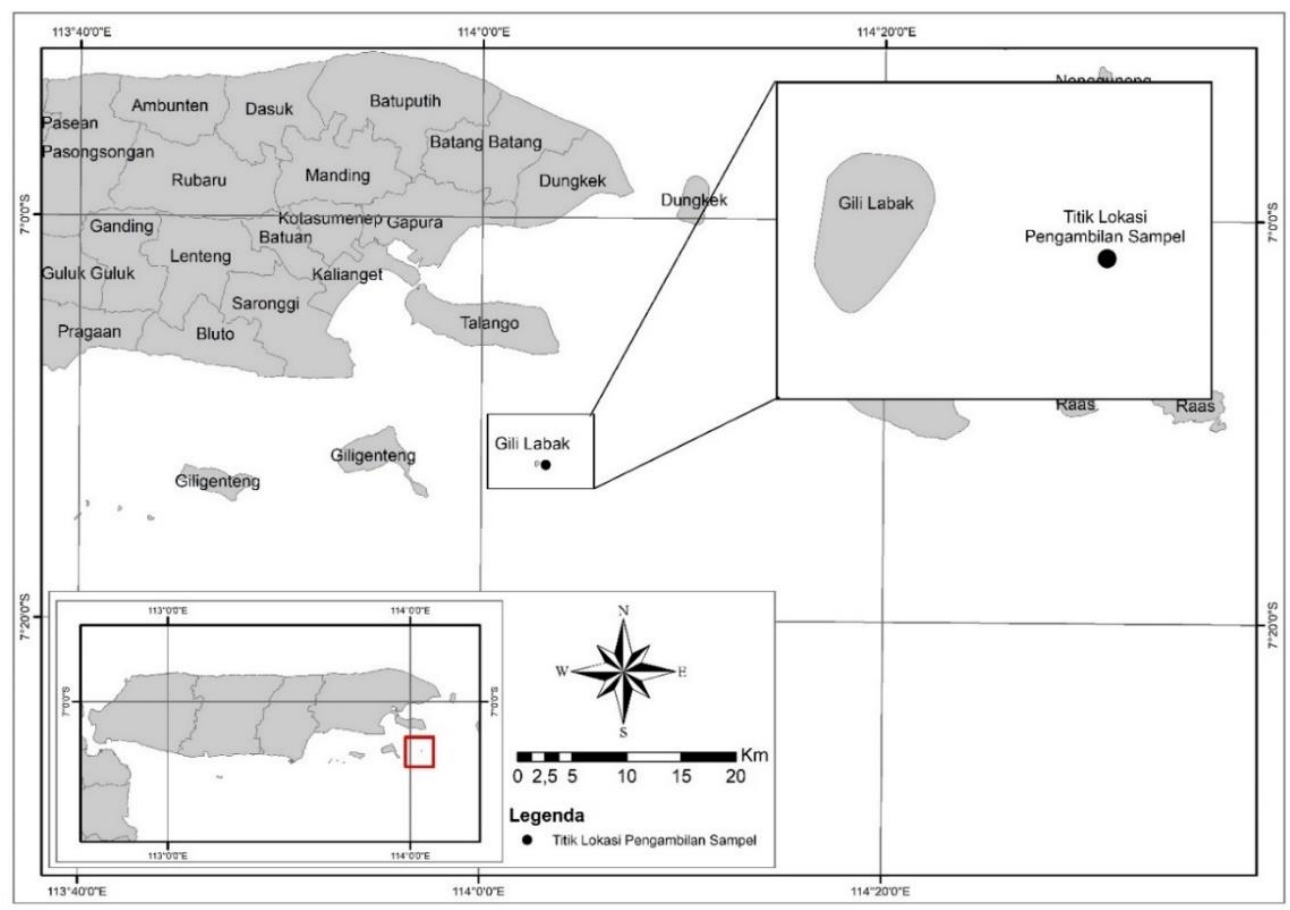

Gambar 1. Titik Lokasi Pengambilan Sampel Sinularia sp. 
kemudian dipanaskan selama 10 menit pada suhu $90^{\circ} \mathrm{C}$ dan di homogenkan menggunakan vortex sesekali setelah 5 menit serta dicentrifuge dengan kecepatan 12.000 rpm selama 10 menit. Konsentrasi DNA diukur menggunakan Spektrofotometer Nano Drop 2000m. Ekstraksi DNA disimpan dalam freezer dengan suhu $-20^{\circ} \mathrm{C}$.

\section{Amplifikasi PCR 16S rDNA (Sabdono dan Radjasa, 2006)}

Amplifikasi PCR 16S rDNA adalah metode standar yang digunakan untuk mengecek filogenetik dan keanekaragaman mikroorganisme laut (Sabdono dan Radjasa, 2006) salah satunya bakteri simbion Sinularia sp. Primer yang digunakan dalam analisa filogenetik bakteri simbion Sinularia sp. untuk PCR 16s rDNA adalah primer universal 27F (5'AGAGTTTGATCMTGGCTCAG3') dan primer spesifik eubacteria 1492R (5'TACGGYTACCTTGTTACGACTT-3') merujuk pada Lane (1991). Komposisi produk PCR yang digunakan GoTaq ${ }^{\circledR}$ Green Master Mix Promega (12,5 $\mu \mathrm{L})$, primer $27 \mathrm{~F}(1 \mu \mathrm{L})$, primer $1492 \mathrm{R}(1 \mu \mathrm{L})$, template DNA $(1 \mu \mathrm{L})$ and $\mathrm{ddH} 2 \mathrm{O}(9,5 \mu \mathrm{L})$, sehingga total produk PCR yaitu $25 \mu \mathrm{L}$. Perlakuan temperatur yang digunakan PCR 16S rDNA ini yaitu tahap denaturasi awal menggunakan suhu $95^{\circ} \mathrm{C}$ selama 3 menit, denaturasi menggunakan suhu $95^{\circ} \mathrm{C}$ selama 1 menit, tahap annealing menggunakan suhu $55^{\circ} \mathrm{C}$ selama 1 menit, dan tahap extension menggunakan suhu $72^{\circ} \mathrm{C}$ selama 1 menit. Pengujian dilakukan di laboratorium Tropical Marine Biotechnology, UNDIP.

\section{Pembuatan Pohon Filogenetik (Altschul et al., 1997; Radjasa et al., 2008)}

Produk PCR dilakukan dianalisis sekuen DNA kemudian produk dianalisa menggunakan koneksi internet melalui program pelacakan database Basic Local Alignment Search Tool (BLAST) pada laman National Center for Biotechnology Information, National Institute for Health, USA yaitu www.ncbi.nlm.nih.gov (Altschul et al., 1997; Radjasa et al., 2008). Sekuens yang diperoleh selanjutnya diolah menggunakan software MEGA 6. Pohon filogenetik dilakukan dengan cara mensejajarkan seluruh sekuens dan sekuens pembandingnya menggunakan analisis algortima metode Neighbor-Joining (NJ) dan pengujian nilai bootstrap 10000 kali.

\section{HASIL DAN PEMBAHASAN}

Karang lunak secara alamiah memproduksi 60\% substansi bioaktif (Higa et al., 2001; Sheu et al., 2002) berupa senyawa metabolit sekunder diantaranya steroid, steroid glikosida dan terpenoid yang berfungsi sebagai antibakteri patogen (Wang et al., 2012). Jenis dan struktur kimia metabolit sekunder yang dihasilkan oleh karang lunak beraneka ragam dan bersifat unik (Minh et al., 2011; Blunt et al., 2013). Senyawa ini diproduksi oleh organisme saat kebutuhan metabolisme primer tercukupi, sehingga senyawa metabolit sekunder cenderung digunakan untuk mekanisme evolusi dan bahan untuk adaptasi lingkungan (Yang et al., 2018). Kemampuan ektrak Sinularia sp. dalam menghambat pertumbuhan bakteri tidak lepas dari peran kandungan senyawa metabolit sekunder yang dihasilkan oleh biota laut ini. Salanggon et al., (2020) melaporkan Sinularia sp. memproduksi beberapa senyawa meatabolit sekunder diantaranya turunan dari golongan alkaloid, flavonoid, saponin, dan steroid. Senyawa steroid yang terkandung pada karang lunak digunakan sebagai materi biologis untuk menghambat aktivitas inflamasi, kanker, bakteri dan alergi (Jia et al., 2005).

Ekstrak karang lunak dari genus Sinularia sp. memiliki kemampuan menghambat pertumbuhan bakteri patogen yang kuat (Rozirwan et al., 2014). Berdasarkan studi literatur hasil penelitian yang pernah dilaksanakan sebelumnya menyatakan bahwa ekstrak Sinularia sp. mampu menghambat pertumbuhan bakteri gram negatif diantaranya menghambat pertumbuhan bakteri Bacillus subtilis dengan konsentrasi hambat minimum (MIC) mencapai $7,8 \mathrm{ug}^{\mathrm{L}} \mathrm{L}^{-1}$ dan bakteri Escherichia coli mencapai 62,5 ug.L-1 (Aboutabl et al., 2013). Karang lunak Sinularia sp. yang diekstrak menggunakan fraksi ethanol juga mampu menghambat aktivitas bakteri Escherichia coli dengan membetuk diameter zona hambat sebesar 1,763 $\pm 1,74 \mathrm{~cm}$ dan bakteri Staphylococcus aureus sebesar 1,743 $\pm 2,29 \mathrm{~cm}$ Tanod et al., (2018). Beberapa hasil penelitian sebelumnya ini menunjukkan bahwa pemanfaatan ekstrak Sinularia sp. sebagai anti Escherichia coli sudah sering dikaji dan digunakan.

Hasil pengujian aktivitas anti bakteri Escherichia coli menggunakan isolat bakteri simbion karang lunak dari perairan pulau Gili Labak-Madura tertera pada Tabel 1. Tabel 1 menunjukkan 
bahwa zona hambat bakteri menggunakan metode overlay dan metode difusi menggunakan media ZoBell 2216E diperoleh dari 4 isolat bakteri dan hanya ada 1 isolat yang mengindikasikan adanya kemampuan menghambat aktivitas antibakteri Escherichia coli. Indikator terjadinya aktivitas anti bakteri Escherichia coli tersebut ditunjukkan dengan terbentuknya zona bening yang di sekitar kertas cakram yang telah ditempatkan diatas permukaan biakan bakteri Escherichia coli. Hasil pengujian difusi agar ditemukan isolat dengan kode L2.5 memiliki diameter zona hambat lebih besar yaitu sebesar 2,207 $\pm 0,401 \mathrm{~cm}$ (Tabel 1). Diameter zona hambat bakteri Escherichia coli dari bakteri simbion Sinularia sp. yang berasal dari perairan Gili Labak ini termasuk kategori kuat dengan ukuran diameter yang lebih besar jika dibandingkan hasil penelitian sebelumnya. Katiandagho et al., (2019) menyatakan karang Sinularia sp. yang diekstrak menggunakan fraksi metanol dapat menghasilkan daya hambat bakteri Escherichia coli sebesar 1,267 cm sedangkan pada fraksi kloroform sebesar $1,05 \mathrm{~cm}$. Hal ini mengindikasikan bahwa penggunaan bakteri yang bersimbion dengan karang lunak Sinularia sp. sebagai antibakteri bakteri Escherichia coli berpeluang besar dan konservatif dibandingkan penggunaan ekstrak karang lunak Sinularia sp. secara langsung.

Identifikasi jenis bakteri simbion karang lunak Sinularia s. aktif pada isolat dengan kode L2.5 perlu dilakukan untuk memastikan jenis bakteri pada isolat tersebut. Pengujian jenis bakteri pada isolat ini dilakukan dengan uji molekuler berdasarkan pendekatan genetiknya menggunakan 16S rDNA. Hasil identifikasi secara molekuler ditunjukkan pada Tabel 2 dan Gambar 2.

Tabel 1 Hasil uji aktifitas anti bakteri dan uji difusi dari bakteri simbion Sinularia sp.

Kode Isolat $\quad$ Uji aktifitas anti bakteri dan uji difusi bakteri simbion Sinularia sp. Aktivitas antibakteri Diameter Zona Hambat $(\mathrm{cm})$

L2.5 $+2,207 \pm 0,401$

Tabel 2 Karakteristik molekuler dari bakteri simbion Sinularia sp.

\begin{tabular}{lcc}
\hline \multirow{2}{*}{ Kode Isolat } & \multicolumn{2}{c}{ Karakteristik molekuler dari bakteri simbion Sinularia sp. } \\
\cline { 2 - 3 } L2.5 & Kerabat dekat & Kemiripan (Simillarty) \\
\cline { 2 - 3 } & Virgibacillus marismortui & $100 \%$ \\
\hline
\end{tabular}

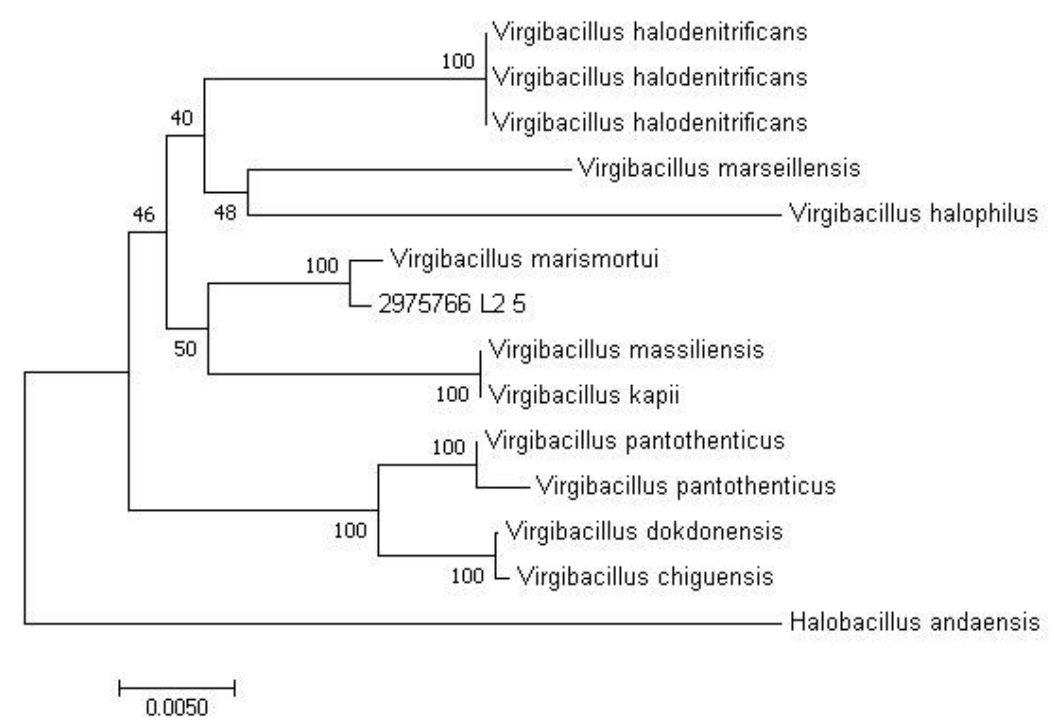

Gambar 2. Pohon filogenetik 16s menggunakan metode Neighbor-joining dari simbion bakteri Sinularia sp. berpotensi sebagai antibakteri Escherichia coli. 
Tabel 2 menunjukkan bahwa hasil analisis filogenetik molekuler menunjukkan bahwa isolat bakteri simbion karang lunak Sinularia sp. aktif sebagai anti bakteri Escherichia coli kuat tersebut adalah Virgibacillus marismortui dengan kemiripan 100\%. Virgibacillus marismortui merupakan jenis bakteri yang berkerabat dekat dengan Virgibacillus massiliensis dan Virgibacillus kapii (Gambar 2). Genus Virgibacillus merupakan klasifikasi bakteri yang tergolong gram positif motil dan pembentuk endospora, serta memiliki sifat halofilik (Peng et al., 2009). Terdapat 16 spesies yang ditemukan dari genus ini saat ini (Heyndrickx et al., 1998).

Bakteri Virgibacillus marismortui merupakan kelompok bakteri yang bersifat motil. Bakteri ini memiliki karakter visual koloni yang melingkar dan tidak beraturan, menonjol, dan berwarna putih krem dengan diameter 2-6 mm (Tanasupawat et al., 2010). Virgibacillus marismortui hidup pada kondisi aerobic pada kisaran suhu yang luas yaitu $15-50^{\circ} \mathrm{C}, \mathrm{pH}$ berkisar $6,0-8,0$ dan tumbuh optimal dengan kadar salinitas yang tinggi atau dikenal dengan sebutan bakteri halofilik (Arahal et al., 1999). Bakteri halofilik adalah kelompok bakteri yang pertumbuhannya tergantung pada kadar $\mathrm{NaCl}$ (Pelczar dan Chan, 1988). Kadar $\mathrm{NaCl}$ yang didiami sebagai habitat bakteri halofilik ini berkisar antara 2\% (setara dengan 0,3 M) hingga 30\% (setara dengan $5 \mathrm{M}$ ) (Ford, 1993). Bakteri halofilik diklasifikasikan tiga yaitu spesies halofil rendah (spesies halofilik yang tumbuh optimal pada $2-5 \% \mathrm{NaC}$ ), spesies halofil sedang (spesies halofilik yang tumbuh optimal pada $5-20 \mathrm{NaCl}$ ) dan jenis halofil yang ekstrim (spesies halofilik yang tumbuh optimal pada kadar garam sekitar 20$30 \% \mathrm{NaCl}$ ) (Dassarma dan Arora, 2001).

\section{KESIMPULAN}

Potensi bakteri simbion karang lunak Sinularia sp. sebagai anti bakteri Escherichia coli dari Perairan Pulau Gili Labak Madura teridentifikasi pada Isolat L2.5 dengan indikator terbentuknya diameter zona hambat sebesar 2,207 $\pm 0,401 \mathrm{~cm}$. Strain bakteri aktif di Isolat L2.5 adalah Virgibacillus marismortui dengan kemiripan $100 \%$. Hasil penelitian ini menjadi informasi awal yang dapat digunakan sebagai referensi untuk mengoptimalkan potensi pemanfaatan bakteri Virgibacillus marismortui di bidang bioteknologi laut khususnya industri farmasi di masa yang akan datang.

\section{UCAPAN TERIMAKASIH}

Terima kasih disampaikan kepada Lembaga Penelitian dan Pengabdian Masyarakat Universitas Trunojoyo Madura melalui Program Hibah Penelitian Mandiri UTM 2017 dengan nomor kontrak penelitian: 2717/UN46.3.1/PN/2017.

\section{DAFTAR PUSTAKA}

Altschul, S.F., Madden, T.L., Schäffer, A.A., Zhang, J., Zhang, Z., Miller, W. \& Lipman, D.J. 1997. Gapped BLAST and PSI-BLAST: A New Generation of Protein Database Search Programs. Nucleic Acids Research, 25(17):3389-3402. DOI: 10.1093/nar/25.17.3389.

Aboutabl, E.S.A., Azzam, S.M., Michel, C.G., Selim, N.M., Hegazy, M.F., Ali, A.H. \& Hussein, A.A. 2013. Bioactive Terpenoids from The Red Sea Soft Coral Sinularia polydactyla. Natural Product Research, 27(23):2224-2226. DOI: 10.1080/14786419.2013.805333.

Aceret, T.L., Coll, J.C., Uchio, Y. \& Sammarco, P.W. 1998. Antimicrobial Activity of The Diterpenes Flexibilide and Sinulariolide Derived from Sinularia flexibilis Quoy and Gaimard 1833 (Coelenterata: Alcyonacea, Octocorallia). Comparative Biochemistry and Physiology Part C, 120(1):121-126. DOI: 10.1016/S0742-8413(98)00032-2.

Ahmed, A.F., Tai, S.H., Wu, Y.C. \& Sheu, J.H. 2007. Sinugrandisterols A-D, Trihydroxysteroids from The Soft Coral Sinularia grandilobata. Steroids, 72(4):368-374. DOI: 10.1016/j.steroids. 2007.01.001

Arahal, D.R., Marquez, M.C., Volcani, B.E., Schleifer, K.H. \& Ventosa, A. 1999. Bacillus marismortui sp. nov., A New Moderately Halophilic Species from The Dead Sea. International Journal of Systematic Bacteriology, 49(2):521-530. DOI: 10.1099/00207713-49-2-521. 
Benson, H.J. 2002. Microbiological Applications a Laboratory Manual in General Microbiology, Ed.8, The Mcgraw-Hill Companies, New York.

Blunt, J.W., Copp, B.R., Keyzers, R.A., Munro, M.H.G. \& Prinsep, M.R. 2013. Marine Natural Products. Natural Product Report, 30(2):237-323. DOI: 10.1039/c2np20112g.

Chen, W., Li, Y. \& Guo, Y. 2012. Terpenoids of Sinularia Soft Corals: Chemistry and Bioactivity. Acta Pharmaceutica Sinica B, 2(3):227-237. DOI: 10.1016/j.apsb.2012.04.004.

Chen, D., Cheng, W., Liu, D., Ofwegen, L. V., Proksch, P. \& Lin, W. 2014. Capillosananes S-Z, New Sesquiterpenoids from The Soft Coral Sinularia capillosa. Tetrahedron Letters, 55(19):3077-3082. DOI: 10.1016/j.tetlet.2014.03.132.

Cheng, S.Y., Chuang, C.T., Wen, Z.H., Wang, S.K., Chiou, S.F., Hsu, C.H., Dai, C.F., \& Duh, C.Y., 2010. Bioactive Norditerpenoids from The Soft Coral Sinularia gyrosa. Bioorganic \& Medicinal Chemistry, 18(10):3379-3386. DOI:10.1016/j.bmc.2010.04.012.

DasSarma, S. \& Arora, P. 2001, Halophiles: Encylopedia of Life Sciences, Nature Publishing Group, USA.

Dewanto, D.K., Finarti, Hermawan, R., Ndobe, S., Haryadi, P.H. \& Tanod, W.A. 2019. Aktivitas antioksidan ekstrak karang lunak asal Teluk Palu, Sulawesi Tengah, Indonesia. Jurnal Pengolahan dan Bioteknologi Kelautan dan Perikanan, 14(2):163-178. DOI: 10.15578/jpbkp. v14i2.583

Fattorusso, E., Luciano, P., Putra, M.Y., Taglialatela-Scafati, O., Ianaro, A., Panza, E. \& Cerrano, C., 2011. Chloroscabrolides, Chlorinated Norcembranoids from The Indonesian Soft Coral Sinularia sp. Tetrahedron, 67(41):7983-7988. DOI: 10.1016/j.tet.2011.08.024.

Ford, T.E. 1993. Aquatic Microbiology an Ecological Approach, Blackwell Scientific Publication, Boston.

Heyndrickx, M., Lebbe, L., Kersters, K., De, V.P., Forsyth, G. \& Logan, N.A. 1998. Virgibacillus: A New Genus to Accommodate Bacillus Pantothenticus (Proom, Knight 1950) Emended Description Virgibacillus pantothenticus. International Journal of Systematic Bacteriology, 48(1):99-106. DOI: 10.1099/00207713-48-1-99.

Higa, T., Tanaka, J., Ohtani, I.I., Musman, M., Roy, M.C. \& Kuroda, I., 2001. Bioactive Compounds from Coral Reef Invertebrates. Pure and Applied Chemistry, 73(3):589-593. DOI: 10.1351/pac200173030589.

Jia, R., Guo, Y., Mollo, E. \& Cimino, G. 2005. Two New 19-oxygenated Polyhydroxy Steroids from The Hainan soft coral Sinularia sp.. Natural Product Research, 19(8):789-794. DOI: 10.1080/ 14786410500123833.

Kamel, H.N. \& Slattery, M. 2005. Terpenoids of Sinularia: Chemistry and Biomedical Applications. Pharmaceutical Biology, 43(3):253-269. DOI: 10.1080/13880200590928852.

Katiandagho, L., Wewengkang, D.S. \& Sudewi, S. 2019. Aktivitas Antibakteri Ekstrak dan Fraksi Karang Lunak Sinularia sp. di Teluk Manado. Pharmacon, 8(1):114-119. DOI: 10.35799/pha. 8.2019.29244

Lane, D.J, 1991. 16S/32S rRNA Sequencing. In: Stackrbrandt, E. \& Goodfellow M., 2013. Nucleiuc Acid Techniques in Bacterial Systematics, John Wiley and Sons Inc, New York.

Lin, Y.S., Chen, C.H., Liawa, C.C., Chen, Y.C., Kuo, Y.H. \& Shen, Y.C. 2009. Cembrane Diterpenoids from The Taiwanese Soft Coral Sinularia flexibilis. Tetrahedron, 65(45):91579164. DOI: 10.1016/j.tet.2009.09.031.

Minh, C.V., Kiem, P.V., Nhiem, N.X., Cuong, N.X., Thao, N.P., Nam, N.H., Anh, H.L.T., Tung, D.C., Thuy, D.T.T., Kang, H.K., Jang, H.D. \& Kim, Y.H. 2011. Cytotoxic and Antioxidant Activities of Diterpenes and Sterols from The Vietnamese Soft Coral Lobophytum compactum. Bioorganic \& Medicinal Chemistry Letters, 21(7):2155-2159. DOI: 10.1016/j.bmcl.2011.01. 072.

Muhsoni, F.F. 2017. Potensi dan Pengelolaan Pulau Gili Labak dan Kajian Pulau di Sumenep, UTMpress, Bangkalan.

Pelczar, M.J. \& Chan, E.C.S., 1988, Dasar-dasar Mikrobiologi, Universitas Indonesia Press, Jakarta.

Peng, Q.Z., Chen, J., Zhang, Y.Q., Chen, Q. H., Peng, D.J., Cui, X.L., Li. W.J. \& Chen, Y.G., 2009. Virgibacillus zhangjiangensis sp. nov., A Marine Bacterium Isolated from Sea Water. Antonie van Leeuwenhoek, 96(4):645-652. DOI: 10.1007/s10482-009-9381-0. 
Putra, M.Y., Lanaro, A., Panza, E., Bavestrello, G., Cerrano, C., Fattorusso, E. \& TaglialatelaScafati, O., 2012. Sinularioside, A Triacetylated Glycolipid from The Indonesian Soft Coral Sinularia $s p$., is An Inhibitor of No Release. Bioorganic \& Medicinal Chemistry Letters, 22(8):2723-2725. DOI: 10.1016/j.bmcl.2012.02.102.

Radjasa, O.K., Sabdono, A., Junaidi, A. \& Zocchi, E., 2007. Richness of Secondary MetaboliteProducing Marine Bacteria Associated with Sponge Haliclona Sp. International Journal of Pharmacology, 3(3):275-279. DOI:10.3923/ijp.2007.275.279.

Radjasa, O.K., Sabdono, A., Wiese, J. \& Imhoff, J.F. 2008. Coral as Source of Bacteria with Antimicrobial Activity. Journal of Coastal Development, 11(3):121-130.

Rajaram, S., Ramesh, D., Ramulu, U., Anjum, M., Kumar, P., Murthy, U.S.N., Sastry, G.N. \& Venkateswarlu, Y. 2014. Chemical Examination of The Soft Coral Sinularia kavarattiensis and Evaluation of Antimicrobial Activity. Indian Journal of Chemistry, 53(8): 1086-1090.

Riyadi, P.H., Wahyudi, D. \& Tanod, W.A. 2019. Effects of Dichloromethane Sarcophyton sp.p. extract on the Lipopolysaccharide-induced Expression of Nuclear Factor-kappa B and Inducible Nitric Oxide Synthase Inmice. Veterinary World, 12(12):1897-1902. DOI: 10.14202/ vetworld.2019.1897-1902.

Rozirwan, Bengen, D.G., Zamani, N.P., Effendi, H. \& Chaidir. 2014. Screening on The Potential Bioactive Compounds of Antibacterial Activity in Soft Coral Collected from South Bangka Island Waters and Lampung Bay. Journal of Tropical Marine Science and Technology, 6(2): 283-295. DOI: 10.29244/jitkt.v6i2.9005.

Sabdono, A. \& Radjasa, O.K. 2006. Anti-Bacterial Property of A Coral-Associated Bacterium Bacillus sp Against Coral Pathogenic BBD (Black Band Disease). Journal of Coastal Development, 9(3):175-182.

Salanggon, A.M. \& Finarti. 2016, Struktur Populasi Rekrut Karang Hermatifik pada Metode Fish Home di Teluk Palu. Journal of Fisheries, Marine and Aquatic Science, 1(1):33-38.

Salanggon, A.M., Aswani, S., Hasanuddin, A., Hermawan, R., Riyadi, P.H., Dewanto, D.K. \& Tanod, W.A. 2020. Aktivitas Antibakteri Ekstrak Karang Lunak Sinularia sp.. dengan Metode Broth-Dilution. Jurnal Kelautan Nasional, 15(3):153-164.

Shaaban, M., Shaaban, K.A. \& Ghani, M.A. 2013. Hurgadacin: A New Steroid from Sinularia polydactyla. Steroids, 78(9):866-873. DOI: 10.1016/j.steroids.2013.05.006.

Sheu, J.H., Ahmed, A.F., Shiue, R.T., Dai, C.F. \& Kuo, Y.H. 2002. Scabrolides A-D, Four New Norditerpenoids Isolated from The Soft Coral Sinularia scabra. Journal of Natural Product, 65(12):1904-1908. DOI: 10.1021/np020280r

Tanasupawat, S., Chamroensaksri, N., Kudo, T. \& Itoh T. 2010. Identification of Moderately Halophilic Bacteria from Thai Fermented Fish (pla-ra) and Proposal of Virgibacillus siamensis sp.nov. Journal of General and Applied Microbiology, 56(5):369-379. DOI: 10.2323/jgam.56. 369

Tanod, W.A., Aristawati, A.T., Putra, M.Y. \& Muliadin. 2018. Soft Coral (Sinularia sp.) Extracts with Antibacterial Activity. Omni Akuatika, 14(1):108-117. DOI: 10.20884/1.oa.2018.14.1.375.

Tanod, W. A., Yanuhar, U., Maftuch, Wahyudi, D. \& Risjani, Y. 2019. DPPH Scavenging Property of Bioactives from Soft Corals Origin Palu Bay, Central Sulawesi, Indonesia, Proceeding of 1st International Conference on Fisheries and Marine Science, Ternate, Oct 10-14.

Wang, S.K., Hsieh, M.K. \& Duh, C.Y. 2012. Three New Cembranoids from The Taiwanese Soft Coral Sarcophyton ehrenbergi. Marine Drugs, 10(7):1433-1444. DOI: 10.3390/md10071433.

Walsh, P. S., Metzger, D. A., \& Higuchi, R., 1991. Chelex 100 as a Medium for Simple Extraction of DNA for PCR-based Typing from Forensic Material. Biotechniques, 10(4):506-513.

Yang, L., Wen, K.S., Ruan, X., Zhao, Y.X., Wei, F., \& Wang, Q., 2018. Response of Plant Secondary Metabolites to Environmental Factors. Molecules, 23(762):1-26. DOI: 10.3390/ molecules23040762. 